\title{
"Prevalence of the Tobacco Use in Rural Tea Industrial and Oil Operated Areas in Assam and Assessment of the Implementation of the Cigarette and Other Tobacco Products Act (Cotpa-2003) And Sequences of Assam Health Bill-2013"
}

\author{
Nani Daflary \\ Assam Oil School of Nursing Indian Oil Corporation Ltd. \\ Assam Oil Division Digboi, Assam, India
}

\begin{abstract}
Tobacco use is a global socio-economic hazard and medical malady. Tobacco is all pervasive in the social life of our country. The incidence of tobacco is persisting and spreading in all walks of our modern society. The paper focuses on different dimensions of Tobacco and its harmful effects on the physical, social life of the country. The analysis portraits that $60 \%$ of the respondents were tobacco consumers with Betel Leave and Nuts /Zarda Pan out of which $71.43 \% \%$ were female and $55.56 \%$ were male followed by $50 \%$ of them were tobacco buyer in the form of cigarette out of which $62.96 \% \%$ are male and $16.67 \%$ are female. Use of cigarette was seen to be followed by Bidi (41.30\%), Khaini (35.33\%) and Gutkha (28\%). It also studied attitude of respondents in causal and consequential dimensions, association of its use demography and role of civil society in controlling tobacco use. It found strong association between attitudes to deadly consequences. However, as respondents were unaware of ban on use. It also found that on role of civil society, 50\% of respondents were in favour of NGO initiatives, while 34\% wanted self awareness and self help to distract it. If civil society is interested in no tobacco zone and wants intervention through people's preference, psychological dynamics of change has to address accordingly. The Cigarettes and Other Tobacco Products (COTPA) Act was developed to curb this epidemic in India in 2003 and endorsed in Assam by establishing the State Nodal Cell at Metro Guwahati in October 2007. Simultaneously, two (2) District Nodal Cell was developed at Kamrup Metro and Jorhat district of Assam in November, 2008 as a Tobacco Cessation march in Assam. The Assam is the first state all over the India where the Government of Assam convinced to the Assembly in the month of July, 2013 to pass the Assam Health (Prohibition of Manufacturing, Advertisement, Trade, Storage, Distribution, Sale and Consumption of Zarda, Guthka, Panmasala etc, containing Tobacco) Bill-2013. The Anti-Tobacco Bill (Assam Health Bill-13) introduced by the Assam Government last year i.e. 2013 came into force from $13^{\text {th }}$ February, 2014, Health Minister Dr. Himanta Biswa Sarma told. The Anti-Tobacco Bill (Assam Health Bill-13) introduced by the Assam Government last year i.e. 2013 came into force from $13^{\text {th }}$ February, 2014 declared in assembly. There is lack of awareness programme at Digboi, Tinsukia district, Assam for implementation of COTPA \& the sequences the Assam Health Bill-2013. With the growing evidence of harmful and hazardous effects of tobacco, the Government of Assam has played a leadership role in State Tobacco Control and enacted various initiatives to implement the COTPA in a comprehensive way to control the tobacco uses.
\end{abstract}

Keywords: Civil Society, Controlling Tobacco, social life

\section{Introduction:}

With the import of tobacco from Portuguese to Mughal Empire, it became popular among the masses in India. The consequential attraction of tobacco made India after China as the second largest producer and consumer of the commodity in the world. ${ }^{[1]-}$. The popularity of tobacco use among adults (15 years and above) is $35 \%$. The overall tobacco user among males is 48 percent and that among females is 20 percent. Almost two out of five $(38 \%)$ adults in rural areas and one out of four (25\%) adult in urban areas use tobacco in some form. ${ }^{[2]}$ The recognition also invited challenge of tobacco use. The gravity of challenges reached such a fatal state that Bhutan (2004), Thailand (2006) and India (2008) implemented ban of smoking in public places. Bhutan is the first country in the world to impose a total ban on tobacco products-sale and use. ${ }^{[3]}$ Some states like Maharashtra and Karnataka restricted smoking in public places. In the case of Maharashtra, specification of the size of boards in English and Marathi were prescribed, declaring certain premises as smoke free. ${ }^{[4]}$ Tobacco smoking was prohibited in all health care establishments, educational institutions, domestic flights, air-conditioned coaches in trains, suburban trains and air-conditioned buses, through a Memorandum issued by the Cabinet Secretariat in $1990^{[5]}$ Since these were mainly Government or administrative orders, they lacked the power of a legal instrument. Without clear enforcement guidelines and awareness of the citizens to their right to smoke-free air, the implementation of this directive remained largely ineffective. Under the Prevention of Food Adulteration Act (PFA) (Amendment) 1990, statutory warnings regarding harmful health effects were made mandatory for 
pan masala and chewing tobacco. ${ }^{[6]}$ The statutory word of warning "cigarette smoking is injurious to health" is known to all, yet without benefit and advantage. Tobacco smoking was forbidden in all Hospitals, educational establishment, domestic air travel, trains, buses However, it lacks a statute as a legal authority.

Tobacco use is a major public health challenge in India with 275 million adults consuming different tobacco products. In India, 800,000-900,000 people die annually due to diseases attributable to tobacco. The government of India has taken several measures, including legislation to control tobacco intake. ${ }^{[7]}$ Government of India has taken various initiatives for tobacco control in the country. Besides enacting comprehensive tobacco control legislation (COTPA, 2003), India was among the first few countries to ratify WHO the Framework Convention on Tobacco Control (WHO FCTC) in 2004. The National Tobacco Control Programme was piloted during the $11^{\text {th }}$ Five Year Plan which is under implementation in 42 districts of 21 states in the country. ${ }^{[8]}$

Assam (latitude $26.00 \mathrm{~N}$ and longitude $93.00 \mathrm{E}$ ) exhibits alarming rates of growth of tobacco use. About $23 \%$ women, $72 \%$ man use any form of tobacco and 36\% use cigarettes/bidis. (Source: NFHS-3, 200506). Looking into the gravity of harmful effect of tobacco use as may be seen in world and Indian Statistics, present study aimed in the following specific objectives:

1. To assess the prevalence and extent of tobacco use by the people of Tea Industrial and Oil Operated areas in Assam

2. Causal dimensions that facilitate extensive tobacco use.

3. Correspondence between Tobacco Use with Demography

4. Consequences of tobacco on social and economic life of the people and the country.

5. The role of civil society in controlling tobacco use.

6. The assess role of governmental and nongovernmental agencies in prevention of tobacco use in Assam. Estimation of prevalence of tobacco with reference to state as a whole and locality as special case require carrying out a social research survey. The survey would enquire underlying social dynamics about the potential hazards and alteration of habit if possible.

The civil society has a great responsibility to curb the tobacco control effectively in each and every corner of the Assam in rural, semi urban and urban areas. Tobacco Cessation is not much easy as we think off. Sustainability is correlated to the complete cessation of the Tobacco. However after a long legal battle and interventions by the civil society, Revised Smoke-free Rules came into effect from $2^{\text {nd }}$ October, 2008. [9] Subsequently the law pertaining to pictorial warnings on tobacco products packages was implemented with effect from $31^{\text {st }}$ May 2009. After getting positive and supportive judgments in other court cases, the Government was forthcoming in notifying laws pertaining to ban on sale to and by minors and sale of tobacco products within 100 yards of educational institutions. For effective implementation and monitoring of anti-tobacco laws and initiatives the Tobacco Control Cells should have dedicated manpower to facilitate the agenda.

\section{Methodology:}

Digboi is a small semi industrial area in Tinsukia District of Assam famous for Oil Refinery run by Oil India Ltd. and Tea Estates. It is a rural industrial area. In order to study the problem, a structured questionnaire with Cronbach's Alpha reliability at 0.725 for Part 1 (18 items) and 0.799 for part II (17 items) and split half reliability 0.716 was attempted by personal interview of 150 respondents in the village of Borbill No-2 and the Hospital Tillah, the sub-urban area, Digboi, Tinsukia District were subjected to preparation of an Excel master sheet which was later on subjected to statistical analysis by SPSS 15.0. The data from master sheet was evaluated by descriptive and inferential statistics. Pearson correlation was used to estimate and test of degree of linear relationship, while Chi- square was used to find out the association between attitudes on prevalence with selected demographic variables. Role of NGO or other related suggestions obtained from respondents were also estimated from relative frequency of response from respondents. One open ended questionnaire for part III was structured by the investigator to assess the effectiveness of the implementation of control measures by State Nodal Cell, Assam and District Nodal Cell of Kamrup Metro and Jorhat district in the state of Assam.

\section{FINDINGS:}

The summary of attitudinal survey is presented in Table 1 . It depicts that $60 \%$ of the respondents were tobacco consumers with Betel Leave and Nuts /Zarda Pan out of which $71.43 \% \%$ were female and $55.56 \%$ were male followed by $50 \%$ of them were tobacco buyer in the form of cigarette out of which $62.96 \% \%$ were male and $16.67 \%$ were female. Use of cigarette was seen to be followed by Bidi (41.30\%), Khaini (35.33\%) and Gutkha (28\%).

In the present study, the most commonly reported tobacco consumers are male than female except tobacco consumers with Betel Leave and Nuts /Zarda Pan. The present study was supported by the National Sample Survey 52 ${ }^{\text {nd }}$ Round and National Family Health Survey-2, where the prevalence of male tobacco consumers was $51.3 \%$ in 1995.1996 and $46.5 \%$ in 1998.1999 . The prevalence of tobacco use among females was $10.3 \%$ and $13.8 \%$, respectively. The result is also supported by the National Household Survey of Drug 
and Alcohol Abuse conducted in 25 states (excluding Jammu and Kashmir) in 2002 reports that $55.8 \%$ of males 12-60 years of age currently use tobacco. The same results were supported by Global Adult Tobacco Survey India, State Programme Implementation Plan 2011-12 highlights that the Current tobacco use in any form: $34.6 \%$ in adults; $47.9 \%$ in males and $20.3 \%$ in females, Current tobacco smokers: $14.0 \%$ of adults; $24.3 \%$ of males and $2.9 \%$ of females, Current cigarette smokers $5.7 \%$ of adults; $10.3 \%$ of males and $0.8 \%$ of females, where bidi smokers: $9.2 \%$ of adults; $16.0 \%$ of males and $1.9 \%$ of females, user of smokeless tobacco: $25.9 \%$ of adults; $32.9 \%$ of males and $18.4 \%$ of females. ${ }^{[10]}$

Table 1: Frequency Analysis of Respondents Attitude on Tobacco Use

\begin{tabular}{|l|l|l|l|l|}
\hline \multirow{2}{*}{ Substance } & \multirow{2}{*}{ Response } & Sex & \multirow{2}{*}{ Total } \\
\cline { 3 - 5 } Cigarette & Mo & $40(37.04 \%)$ & $35(83.33 \%)$ & $75(50.00 \%)$ \\
\hline & Yes & $68(62.96 \%)$ & $7(16.67 \%)$ & $75(50.00 \%)$ \\
\hline \multirow{2}{*}{ Bidi } & No & $52(48.10 \%)$ & $36(85.70 \%)$ & $88(58.70 \%)$ \\
\hline & Yes & $56(51.90 \%)$ & $6(14.30 \%)$ & $61(41.30 \%)$ \\
\hline Betel Leave and Nuts /Zarda Pan & No & $48(44.44 \%)$ & $12(28.57 \%)$ & $60(40.00 \%)$ \\
\hline & Yes & $60(55.56 \%)$ & $30(71.43 \%)$ & $90(60.00 \%)$ \\
\hline Gutkha & No & $74(68.52 \%)$ & $33(78.57 \%)$ & $107(71.33 \%)$ \\
\hline & Yes & $34(31.48 \%)$ & $8(19.05 \%)$ & $42(28.00 \%)$ \\
\hline Khaini & NR & & $1(2.38 \%)$ & $1(0.67 \%)$ \\
\hline & No & $68(62.96 \%)$ & $29(69.05 \%)$ & $97(64.67 \%)$ \\
\hline Total & Yes & $40(37.04 \%)$ & $13(30.95 \%)$ & $53(35.33 \%)$ \\
\hline
\end{tabular}

$\mathrm{NR}=$ Not Reported

Table 2 exposes user's preferences in consumption in recipes of different combination of tobacco products. The preference varied from Cigarette+Bidi $(32 \%)$ followed by Cigarette+ Bidi+ Betel leaves and nuts /zarda pan $(30 \%)$. The lowest preference was seen in $2 \%$ in Betel leaves and nuts /zarda pan+Gutkha, Cigarette+Bidi+ Khaini, Cigarette+Betel leaves and nuts /zarda pan+Gutkha+Khaini, Bidi+Betel leaves and nuts/zarda pan and Khaini (alone). The tobacco market is exploring the potentiality of this taste and preference dimension of users, which civil society has to a role to counter.

Table 2: Distribution of Tobacco Use by sample Respondents

\begin{tabular}{|l|l|l|}
\hline Substance & Frequency & Percent \\
\hline Cigarette & 24 & 16.00 \\
\hline Betel leaves and nuts /zarda pan+Gutkha & 2 & 1.33 \\
\hline Cigarette+Bidi & 32 & 21.33 \\
\hline Cigarette+Bidi+ Khaini & 2 & 1.33 \\
\hline Cigarette+Bidi+Betel leaves and nuts /zarda pan & 30 & 20.00 \\
\hline Cigarette+Bidi+Betel leaves and nuts /zarda pan+Gutkha & 13 & 8.67 \\
\hline Cigarette+Betel leaves and nuts /zarda pan & 7 & 4.67 \\
\hline Cigarette+Betel leaves and nuts /zarda pan+Gutkha & 6.00 \\
\hline Cigarette+Betel leaves and nuts /zarda pan+Gutkha+Khaini & 2 & 1.33 \\
\hline Cigarette+Betel leaves and nuts /zarda pan+Khaini & 2 & 2.00 \\
\hline Cigarette+Gutkha & 3 & 2.00 \\
\hline Bidi+Betel leaves and nuts/zarda pan & 3 & 1.33 \\
\hline Bidi+Betel leaves and nuts /zarda pan+Gutkha & 2 & 2.00 \\
\hline Betel leaves and nuts /zarda pan & 3 & 4.00 \\
\hline Betel leaves and nuts /zarda pan+Gutkha & 6 & 2.00 \\
\hline Betel leaves and nuts /zarda pan+Gutkha+Khaini & 3 & 2.00 \\
\hline Khaini & 3 & 1.33 \\
\hline NR & 2 & 2.67 \\
\hline Total & 4 & 100.00 \\
\hline
\end{tabular}

\section{NR=Not Reported}

The study also made an attempt to study interrelation of consumption of different tobacco product by Pearson correlation. Correlation analysis revealed significantly and positively association of Bidi (0.46) with cigarette which indicated that bidi users prefer entertainment in cigarette. While the cigarette negatively related

$$
\text { www.iosrjournals.org 3|Page }
$$


to khaini $(-0.21)$ indicated that khaini users prefer a little in cigarette. Increase use in any one of them had an increased or decreased tendency to use of others. However, inversely correlated to khaini (-0.16) with Gutkha indicated that strong preference of Guthka has been dominating over Khaini. (Table-3)

Table 3: Pearson Correlations of Tobacco Substances

\begin{tabular}{|l|l|l|l|l|}
\hline & Bidi & $\begin{array}{l}\text { Betel Leave and } \\
\text { Nuts /Zarda Pan }\end{array}$ & Gutkha & Khaini \\
\hline Cigarette & $.460(* *)$ & -.109 & .074 & $-.209(*)$ \\
\hline Bidi & & -.033 & .075 & -.054 \\
\hline $\begin{array}{l}\text { Betel Leave and Nuts } \\
\text { (Zarda Pan) }\end{array}$ & & & .086 & -.023 \\
\hline Gutkha & & & & $-.161(*)$ \\
\hline
\end{tabular}

** Correlation is significant at the 0.01 level (2-tailed).

* Correlation is significant at the 0.05 level (2-tailed).

Factors contributed to tobacco use as reported by respondents (Table 4) revealed that financial factor contributed mostly (31.33\%) followed by psychological attitude (28.67\%) and biological make-up (25.33\%).

Table 4: Attitude of Respondents on underlying Factors of Tobacco Use

\begin{tabular}{|c|c|c|c|c|c|c|c|}
\hline & & \multicolumn{3}{|c|}{ Respondent's View } & \multirow[b]{2}{*}{ Total } & \multirow[b]{2}{*}{ Means } & \multirow[b]{2}{*}{$\begin{array}{l}\text { Contribution } \\
(\%)\end{array}$} \\
\hline & & $\begin{array}{l}\text { Not } \\
\text { contributing }\end{array}$ & $\begin{array}{l}\text { Partially } \\
\text { contributi } \\
\text { ng }\end{array}$ & $\begin{array}{l}\text { Most } \\
\text { contributing }\end{array}$ & & & \\
\hline \multirow[t]{2}{*}{$\begin{array}{l}\text { Biological } \\
\text { factors }\end{array}$} & Frequency & 14 & 98 & 38 & 150 & $\begin{array}{l}11.97 \pm 2.5 \\
7\end{array}$ & 22.31 \\
\hline & Percent & 9.33 & 65.33 & 25.33 & 100 & & \\
\hline \multirow[t]{2}{*}{$\begin{array}{l}\text { Psychological } \\
\text { factors }\end{array}$} & Frequency & 11 & 96 & 43 & 150 & $\begin{array}{l}10.80 \pm 2.7 \\
4\end{array}$ & 20.13 \\
\hline & Percent & 7.33 & 64.00 & 28.67 & 100 & & \\
\hline \multirow[t]{2}{*}{$\begin{array}{l}\text { Interpersonal } \\
\text { factors }\end{array}$} & Frequency & 3 & 112 & 35 & 150 & $\begin{array}{l}10.39 \pm 2.6 \\
4\end{array}$ & 19.37 \\
\hline & Percent & 2.00 & 74.67 & 23.33 & 100 & & \\
\hline \multirow[t]{2}{*}{$\begin{array}{l}\text { Financial } \\
\text { factors }\end{array}$} & Frequency & 14 & 89 & 47 & 150 & $\begin{array}{l}10.01 \pm 2.7 \\
8\end{array}$ & 18.66 \\
\hline & Percent & 9.33 & 59.33 & 31.33 & 100 & & \\
\hline \multirow[t]{2}{*}{$\begin{array}{l}\text { Socio-Cultural } \\
\text { factors }\end{array}$} & Frequency & 3 & 114 & 33 & 150 & $\begin{array}{l}10.49 \pm 2.7 \\
0\end{array}$ & 19.55 \\
\hline & Percent & 2.00 & 76.00 & 22.00 & 100 & & \\
\hline \multirow[t]{2}{*}{ Attitude Level } & Frequency & 21 & 105 & 24 & 150 & & 100.00 \\
\hline & Percent & 14.00 & 70.00 & 16.00 & 100 & & \\
\hline
\end{tabular}

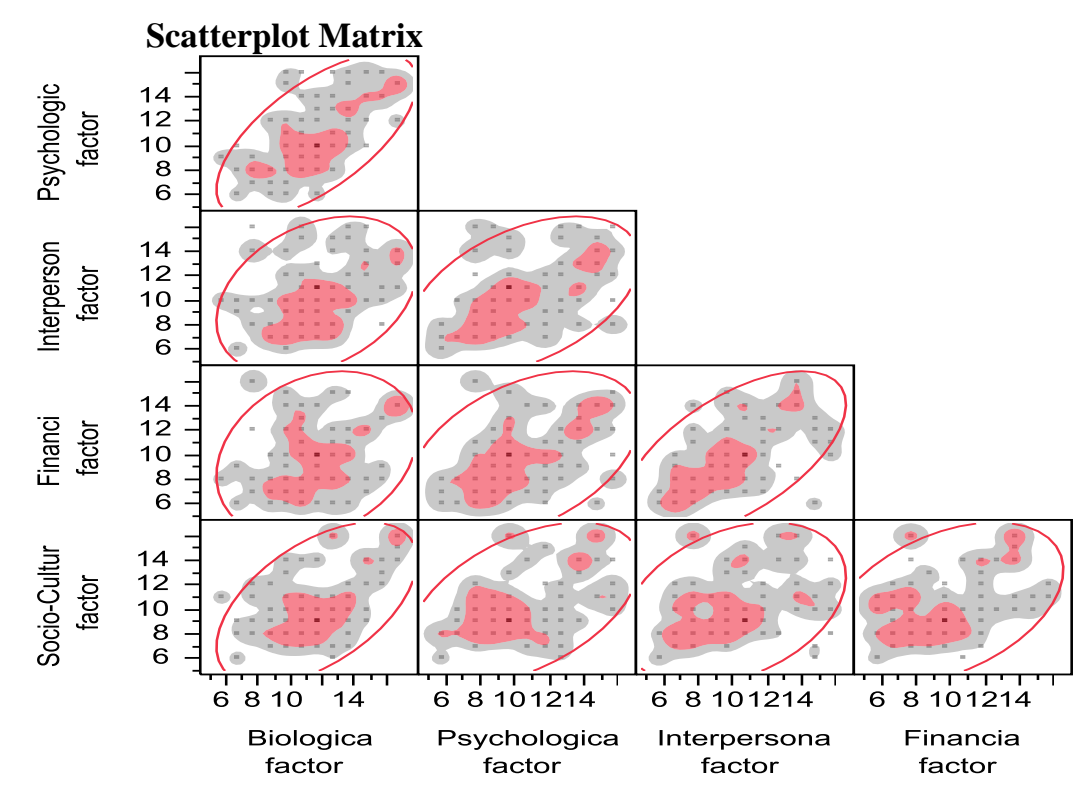

Figure-1: Attitude of Respondents on underlying Factors of Tobacco Use 


\section{Scatter plot Matrix}

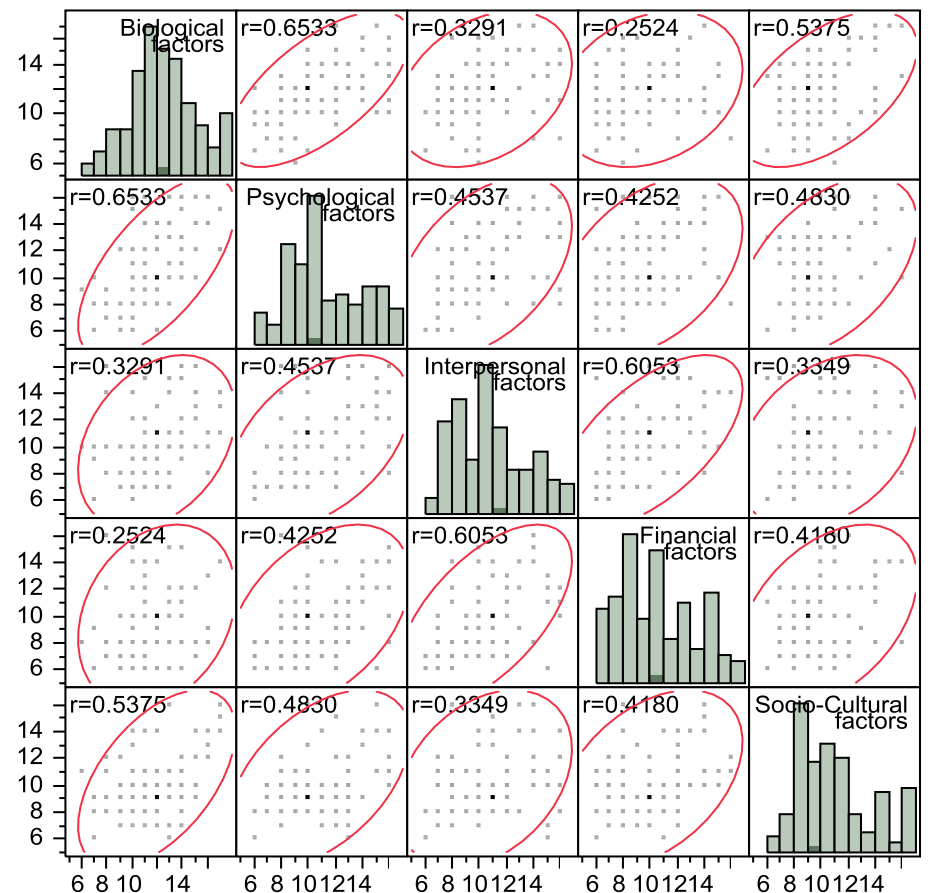

Correlation analysis (Table 5) also revealed that psychological, interpersonal, financial and socio-cultural factors were positively and significantly correlated to each other. It suggests that if policy is to be initiated, it must address all factors simultenously to mitigate the prevalence.

Table 5: Pearson Correlations of different factors in Tobacco Use

\begin{tabular}{|l|l|l|l|l|}
\hline & $\begin{array}{l}\text { Psychological } \\
\text { factors }\end{array}$ & $\begin{array}{l}\text { Interpersonal } \\
\text { factors }\end{array}$ & $\begin{array}{l}\text { Financial } \\
\text { factors }\end{array}$ & Socio-Cultural factors \\
\hline Biological factors & $.653(* *)$ & $.329(* *)$ & $.252(* *)$ & $.537(* *)$ \\
\hline Psychological factors & & $.454(* *)$ & $.425(* *)$ & $.483(* *)$ \\
\hline Interpersonal factors & & & $.605(* *)$ & $.335(* *)$ \\
\hline Financial factors & & & & $.418(* *)$ \\
\hline
\end{tabular}

** Correlation is significant at the 0.01 level (2-tailed).

Knowledge of the tobacco users about the health risk revealed (Table 6) that public attitude is significantly associated with deadly impact of tobacco. However, their attitudes were insignificantly associated to awareness of statutory regulation on ban of tobacco in the state.

Table 6: Attitude Level and Awareness

\begin{tabular}{|l|l|l|l|l|l|l|l|l|}
\hline & & \multicolumn{2}{|l|}{ Attitude Level } & Total & & & \\
\hline \multirow{3}{*}{ Tobaco is } & & $\begin{array}{l}\text { Not } \\
\text { Contributing }\end{array}$ & $\begin{array}{l}\text { Partially } \\
\text { Contributing }\end{array}$ & $\begin{array}{l}\text { Most } \\
\text { Contributing }\end{array}$ & & $\begin{array}{l}\text { Chi_S } \\
\text { quare }\end{array}$ & $\begin{array}{l}\text { d } \\
\text { f }\end{array}$ & $\begin{array}{l}\text { P_Va } \\
\text { lue }\end{array}$ \\
\hline \multirow{3}{*}{ Deadly Practice to life } & No & 6 & 21 & 0 & 27 & $7.14^{*}$ & 2 & 0.03 \\
\cline { 2 - 11 } & Yes & 15 & 84 & 24 & 123 & & & \\
\hline \multirow{3}{*}{$\begin{array}{l}\text { Aware of ban of tobacco by } \\
\text { law }\end{array}$} & No & 9 & 53 & 13 & 75 & 3.55 & 4 & 0.47 \\
\cline { 2 - 10 } & Yes & 12 & 46 & 11 & 69 & & & \\
\cline { 2 - 10 } & NR & 0 & 6 & 0 & 6 & & & \\
\hline
\end{tabular}

$\mathrm{NR}=$ No Response, * Significant at $\mathrm{P}(<0.05)$

The Table 7 depicts that attitude was highly related to age, sex and marital status, residential area, educational status and current occupation. However it is unrelated to religion, type of family and income level. Policy makers may also address these demographic parameters if eradication measures has to undertaken. Awareness and its impact on tobacco consumption are poor among my study subjects. There is an urgent need for reconsideration for more effective awareness, enforcement programme initially. 
Table 7: Association of Tobacco use with demography

\begin{tabular}{|c|c|c|c|c|c|c|c|c|}
\hline & & \multicolumn{3}{|l|}{ Attitude } & \multirow[b]{2}{*}{ otal } & \multirow[b]{2}{*}{$\begin{array}{l}\text { Chi } \\
\text { Square }\end{array}$} & \multirow[b]{2}{*}{ df } & \multirow[b]{2}{*}{ P_Value } \\
\hline & & $\begin{array}{l}\text { Most } \\
\text { Contributing }\end{array}$ & $\begin{array}{l}\text { Not } \\
\text { Contributing }\end{array}$ & $\begin{array}{l}\text { Partially } \\
\text { Contributing }\end{array}$ & & & & \\
\hline \multirow[t]{5}{*}{ Age } & $16-20$ years & 1 & 0 & 6 & 7 & $40.850 * *$ & 8 & $<0.001$ \\
\hline & $20-30$ years & 9 & 3 & 16 & 28 & & & \\
\hline & $30-40$ years & 2 & 5 & 33 & 40 & & & \\
\hline & $>40$ years & 5 & 13 & 48 & 66 & & & \\
\hline & NR & 7 & 0 & 2 & 9 & & & \\
\hline \multirow[t]{2}{*}{ Sex } & Male & 12 & 18 & 78 & 108 & $7.993^{*}$ & 2 & 0.018 \\
\hline & Female & 12 & 3 & 27 & 42 & & & \\
\hline \multirow{4}{*}{$\begin{array}{l}\text { Marital } \\
\text { Status }\end{array}$} & Single & 2 & 12 & 41 & 55 & $20.660 * *$ & 6 & 0.002 \\
\hline & Married & 16 & 9 & 58 & 83 & & & \\
\hline & Divorced & 2 & 0 & 3 & 5 & & & \\
\hline & $\begin{array}{l}\text { Widow/ } \\
\text { widower }\end{array}$ & 4 & 0 & 3 & 7 & & & \\
\hline \multirow[t]{3}{*}{ Religion } & Hindu & 21 & 17 & 81 & 119 & 2.467 & 4 & 0.651 \\
\hline & Muslim & 0 & 0 & 4 & 4 & & & \\
\hline & Christian & 3 & 4 & 20 & 27 & & & \\
\hline \multirow{2}{*}{$\begin{array}{l}\text { Residential } \\
\text { area }\end{array}$} & Rural & 24 & 6 & 45 & 75 & 30.00 ** & 2 & 0.000 \\
\hline & Semi Urban & 0 & 15 & 60 & 75 & & & \\
\hline \multirow{5}{*}{$\begin{array}{l}\text { Educationa } \\
1 \text { status }\end{array}$} & Illiterate & 10 & 0 & 16 & 26 & $34.69 * *$ & 8 & 0.000 \\
\hline & Primary & 12 & 5 & 44 & 61 & & & \\
\hline & Secondary & 1 & 6 & 29 & 36 & & & \\
\hline & Graduate & 1 & 10 & 14 & 25 & & & \\
\hline & Post graduate & 0 & 0 & 2 & 2 & & & \\
\hline \multirow{5}{*}{$\begin{array}{l}\text { Current } \\
\text { Occupation }\end{array}$} & Student & 0 & 0 & 2 & 2 & $19.82^{*}$ & 8 & 0.011 \\
\hline & Unemployed & 15 & 16 & 74 & 105 & & & \\
\hline & $\begin{array}{l}\text { Government } \\
\text { employee }\end{array}$ & 1 & 3 & 8 & 12 & & & \\
\hline & $\begin{array}{l}\text { Private } \\
\text { employee }\end{array}$ & 3 & 2 & 19 & 24 & & & \\
\hline & 5 & 5 & 0 & 2 & 7 & & & \\
\hline \multirow{3}{*}{$\begin{array}{l}\text { Type of } \\
\text { family }\end{array}$} & Joint & 9 & 11 & 64 & 84 & 4.888 & 4 & 0.299 \\
\hline & Nuclear & 14 & 9 & 39 & 62 & & & \\
\hline & Extended & 1 & 1 & 2 & 4 & & & \\
\hline \multirow{6}{*}{$\begin{array}{l}\text { Family } \\
\text { monthly } \\
\text { income(Rs. } \\
\text { ) }\end{array}$} & $<5000$ & 7 & 7 & 33 & 47 & 7.342 & 10 & 0.693 \\
\hline & $5000-10000$ & 12 & 7 & 57 & 76 & & & \\
\hline & $10000-20000$ & 4 & 4 & 9 & 17 & & & \\
\hline & $>20000$ & 0 & 1 & 2 & 3 & & & \\
\hline & NR & 1 & 1 & 2 & 4 & & & \\
\hline & Refused & 0 & 1 & 2 & 3 & & & \\
\hline \multicolumn{2}{|l|}{ Total } & 24 & 21 & 105 & 150 & & & \\
\hline
\end{tabular}

\section{NR= No Response}

\section{$\mathbf{N C}=$ Not contributing, $\mathbf{P C}=$ partially contributing $\mathrm{MC}=$ Most contributing}

Role of civil society in controlling tobacco and prevent the social hazards as reported by respondents was presented in Table 8. Fig:2 It found that 50\% of respondents were in favour of NGO initiatives while 34\% preferred psychological intervention with self awareness and self help measures to repel from tobacco use. If the civil society wants a tobacco free zone and acts according to information about people's choice, psychological dynamics of change has to address in a hurry without delay. India has already taken many tobacco control initiatives including legislative measures, ratification of the WHO FCTC and implementation of the National Tobacco Control Programme. The Indian anti tobacco law is reasonably strong to comply with most of the provisions in the WHO FCTC 
Table 8 Suggestion of Sample Respondents on remedial measure

\begin{tabular}{|l|l|l|}
\hline & Frequency & Percent \\
\hline No Response(Undecided) & 18 & 12.00 \\
\hline $\begin{array}{l}\text { Self Awareness \& self help may } \\
\text { repel from Tobaco Use } \\
\text { (Psychological Intervention) }\end{array}$ & 51 & 34.00 \\
\hline NGO Initiative & 75 & 50.00 \\
\hline Strong Law & 6 & 4.00 \\
\hline Total & 150 & 100.00 \\
\hline
\end{tabular}

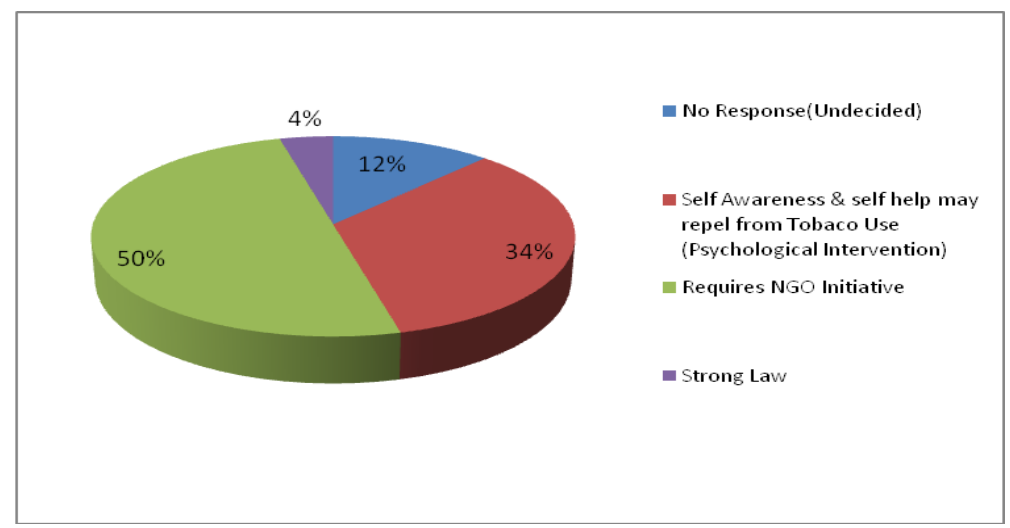

Figure-2 Suggestion of Sample Respondents on remedial measure

\section{Implementation of COTPA and the Sequences of Assam Health Bill-13}

In implementation of various provisions under COTPA lies mainly with the State Governments, effective enforcement of tobacco control law remains a big challenge. To strengthen implementation of the tobacco control provisions under COTPA and policies of tobacco control mandated under the WHO FCTC, the Government of the India piloted National Tobacco Control Programme (NTCP) in 2007-2008. "11] The programme is under implementation in 21 out of 35 States/Union territories in the country. In total, 42 districts including Assam are covered by NTCP at present. This was a major leap forward for the tobacco control initiatives in the country as for the first time dedicated funds were made available to implement tobacco control strategies at the central state and sub-state levels.

In spite of a comprehensive legislation being in place and implementation of NTCP by the Government, many of the states are not able to initiate effective measures for tobacco control. The internal monitoring of implementation of COTPA in 21 States, where the National Tobacco Control Programme is under implementation has revealed that only about half of the states $(52 \%)$ have mechanisms for monitoring provisions under the law. Although 15 states have established challenging mechanism for enforcement of smoke-free rules, only 11 states collected fines for violations of bans on smoking in public places. Similarly, a steering committee for implementation of section-5 (ban on Tobacco advertisements, promotion and sponsorship) has been constituted in 21 states but only 3 states collected fines for the violation of this provision. The total Fine collected by the state of Assam for violation of Section 4, 5, 6 is Rs. 94000 till 2013. (Annexure-I sample copy of Receipt) Similarly, enforcement of a ban on the sale of tobacco products to minors and bans on the sale of tobacco products within 100 yards of educational institutions also remains largely ineffective in many states including Assam. Less than half of the states under the programme have established tobacco cessation facilities at the district level. It is largely because of the failure of the states to recruit manpower under the programme. To facilitate the implementation of NTCP at state and sub state level, the Government developed various Training modules, guides, IEC and advocacy materials. ${ }^{[12] ~[13][14][15][16]}$

Setting up of Tobacco Cessation Clinics in Assam has been one of the major highlights in Tobacco Cessation march. The network of Tobacco Cessation Clinics was expanded in 2005 to cover five new clinics in Regional Cancer Centres (RCCs) in 5 states of which two centers were in the North-Eastern States of Mizoram and Assam, having high prevalence of tobacco use. Assam has three (3) Tobacco Cessation Clinics out of 13 Tobacco Cessation Clinics in 12 states across the country. Two Centres for Nicotine Replacement Therapy were established in Metro Guwahati and Jorhat own. In Jorhat district two (2) villages was declared as Tobacco Free Villages and 3 are in under process. (Table:10)

The total awareness programme conducted in various parts of Assam was nearly 400 till December, 2013. The awareness programme on ill health effect of tobacco use were organised in schools with Audio Visual Aids. A well designed mega campaign i.e. Tobacco Free North-East Campaign was conducted on 1st and 2nd 
March 2014 at the Metro City Guwahati with gracious presence of Mr. Tarun Gogoi, the Chief Minister, Government of Assam, Dr. Himanta Biswa Sarma, the Minister of Education, Health \& F.W. and Implementation of Assam Accord Deptt., many more MLA's of North-Eastern State, all the Governmental Officials of North-East, Jeenat Aman, the film actress, the voice of India Mr. Devajit Saha, the boxer, Mr. Abhijit Baruah, the Guinness Book of record holder for throwing 329 punches on a boxing pad in a minutes and other celebrity of North Eastern State were enlightened the campaign. A mega rally with a slogan-"I Said No Tobacco" was organized in which Hon'ble Chief Minister; Mr. Tarun Gogoi administered "No Tobacco Use" pledge to youth \& students. The rally was followed by a Pledge taking by around 2500 of people at 10:00 am and simultaneously at 10:30 am the same pledge was distributed to the schools/colleges of Assam to for the teachers and students. (Annexure-II Copy of Pledge signed by the Dr. Himanta Biswa Sarma, the minister of Education, Health \& F.W. and implementation of Assam Accord Dept.) The aim was creating public awareness about tobacco use in the region \& reduces health costs. The event created mass awareness \& sensitised the stakeholder against tobacco use, the Regional Director of State Health services, Assam, Mr. Parthojyoti Gogoi, said.

Recently in 2014 a Food Safety cum District Nodal Officer, District Tobacco Control Cell Kamrup Metro, Mr. Samiran Baruah, watched a Bengali Drama in a Drama Festival at Rabindra Bhawan, Guwahati, Assam where a character was live cigarette smoker. He detained the director against the violation of Section-4 instantly. The Grant in aid for State Tobacco Control Cell including salary, training, IEC (Information, education and Communication), School Programme, Awareness Programme (Both privat and public sector) was about 10.00 lacs, (Report of State Nodal Cell and District Nodal Cell of Assam)

The state of Assam with population 26.6 million (Census, 2001) has two hundred and two (202) educational institutions out of which forty nine (49) are Nursing establishments (1 Health University, 8 Collegiate Programme, 21 GNM training School, 18 ANM training School, 1 LHV training centre Source: O/O Joint Director Nursing). Table: 9 illustrate that out of 202 educational establishments, the State Tobacco Control Celll declared 84 Tobacco Free educational establishments. Out of 12 Universities of Assam only one university was declared as Tobacco Free University ie, the Tezpur University and the Campus of Guwahati University was declared as Tobacco Free Campus. The Inter State Bus Terminus (ISBT), Guwahati was also declared as Tobacco Free Zone. The Vice-Cencellor of Dibrugarh University, Mr. Alok Borgohain with synchronization with District Tobacco Control Officer, the JorhatTobacco Control Cell, arranged a meeting in December, 2013 to instigate the Tobacco Free Training Programme with 113 Colleges under the Dibrugarh University.

\begin{tabular}{|c|c|c|c|c|c|c|}
\hline $\begin{array}{l}\text { Sl. } \\
\text { No. }\end{array}$ & $\begin{array}{l}\text { District of } \\
\text { Assam }\end{array}$ & $\begin{array}{l}\text { Tobacco } \\
\text { free } \\
\text { University }\end{array}$ & $\begin{array}{l}\text { Tobacco } \\
\text { Free } \\
\text { School/C } \\
\text { ollege } \\
\end{array}$ & $\begin{array}{ll}\text { Tobacco } & \text { Free } \\
\text { Villages } & \end{array}$ & $\begin{array}{l}\text { Tobacco Free } \\
\text { Zone }\end{array}$ & Remarks \\
\hline 1 & $\begin{array}{l}\text { Metro } \\
\text { Guwahati }\end{array}$ & 0 & 2 & - & 2 & $\begin{array}{l}\text { The following set-up was declared as } \\
\text { Tobacco Free by Assam Tobacco Control } \\
\text { Centre } \\
\text { 1. The B. Baruah College } \\
\text { 2. The Pandu College } \\
\text { 3. The Gauhati University } \\
\text { campus } \\
\text { 4. The ISBT campus } \\
\text { Seven (7) Educational Establishments are } \\
\text { under Tobacco Free Process. }\end{array}$ \\
\hline 2 & $\begin{array}{l}\text { Jorhat } \\
\text { District }\end{array}$ & - & $\begin{array}{l}82 \\
\text { Declared } \\
15 \\
\text { Processin } \\
\mathrm{g}\end{array}$ & $\begin{array}{l}2 \text { Declared } \\
3 \text { Processing }\end{array}$ & - & 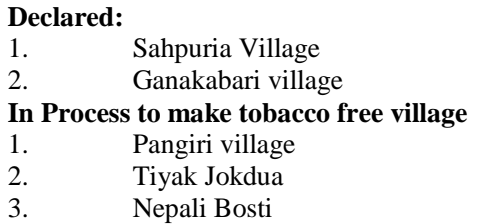 \\
\hline
\end{tabular}

Table-10 The Tobacco Quit Clinic in Assam

\begin{tabular}{|c|c|c|c|}
\hline District & Tobacco Quit Clinic & $\begin{array}{l}\text { Nicotine Replacement } \\
\text { Therapy }\end{array}$ & NGO's Initiatives \\
\hline $\begin{array}{l}\text { METROPOLITAN } \\
\text { GUWAHATI } \\
\text { URBAN }\end{array}$ & $\begin{array}{lr}\text { 1. Mohendra } & \text { Mohan } \\
\text { Choudhury } & \text { Hospital } \\
(\mathrm{MMCH})--1 & \\
\text { 2. Dr. B. Borooah } & \text { Cancer } \\
\text { Institute (BBCI)-1 } & \end{array}$ & $\begin{array}{l}\text { 1) Mohendra Mohan } \\
\text { Choudhury } \\
\text { Hospital-1 }\end{array}$ & $\begin{array}{ll}\text { 1. } & \text { The Voluntary Health } \\
& \text { Association of Assam } \\
\text { 2. } & \text { The Jagriti Cultural Centre } \\
\text { 3. } & \text { The Women Welfare society }\end{array}$ \\
\hline JORHAT & $\begin{array}{l}\text { 1. Jorhat Medical College } \\
\text { Hospitals }\end{array}$ & $\begin{array}{ll}\text { 1) } & \text { Jorhat Medical } \\
\text { College Hospital }\end{array}$ & $\begin{array}{l}\text { 2) The Sankalpa Hikha } \\
\text { 3) The Poribortan Natya Gusthi } \\
\text { (Tiyak) }\end{array}$ \\
\hline Total & 3 & 2 & 5 \\
\hline
\end{tabular}


The table 10 depicts that Assam has three (3) Tobacco Cessation Clinics, two (2) Nicotine Replacement Clinics. In Guwahati there are two (2) Tobacco Cessation Clinics viz. in Mohendra Mohan Choudhury Hospital $(\mathrm{MMCH})$ and Dr. B. Borooah Cancer Institute (BBCI) out of which the BBCI is under grant in Aid of WHO. In Jorhat Medical College Hospital, Jorhat district, Assam the Tobacco Quit Clinic as OPD service and one Nicotine Replacement Clinic was established.

The table 10 also depicts that the total of five (5) NGO's are attached with the activity of State Nodal Cell and District Nodal Cell of Assam in the mean of Awareness programme, Enforcement and Monitoring of Tobacco use under the act of COTPA.

A voice of victim was raised by 10 numbers of patients from Dr. B. Borooah Cancer Institution, Guwahati, Assam to convince the assembly to pass the Assam Health (Prohibition of Manufacturing, Advertisement, Trade, Storage, Distribution, Sale and Consumption of Zarda, Guthka, Pan masala etc, containing Tobacco) Bill-2013. The bill was declared by the Governor, the President of India, Mr. Pranab Mukharjee on $13^{\text {th }}$ February, 2014. It is the great privilege for me to represent the state of Assam for the affirmative and resourceful commencement and audacious initiatives and boldness towards the Cessation of Tobacco for the welfare of the health of the people in the state of Assam. I want to congratulate the government of Assam and the citizen of Assam for the big march for the Prohibition of Manufacturing, Advertisement, Trade, Storage, Distribution, Sale \& Consumption of Zarda, Guthka, Panmasala etc. containing Tobacco.

\section{Conclusion:}

The statistics found in the survey of prevalence of tobacco use in the Tea Industrial and Oil Operated areas in Assam was found to be in alarming dimension of deadly evil. The dynamics of the users in manipulating tobacco product has widened possibility of gaining its momentous in future. The civil society has a great responsibility to face the evil with many faces and control effectively in in rural, semi urban and urban areas of the state. Saying no tobacco is much easier than done. Doing it is correlated to the complete cessation of the tobacco. For effective implementation and monitoring of it strengthening of Tobacco Control Cells under the anti-tobacco laws has no alternative. The Cigarettes and Other Tobacco Products Act (COTPA) has enacted to control tobacco as a major public health challenge in India. The state of Assam has implemented the tobacco control policies and programmes with various levels of success initially for two district of Assam which is planned to be extended to another 10-12 districts (viz. Barpeta, Dhemaji, Dibrugarh, Dhubri, Golaghat, Kamrup Rural, Kukrajhar, Kasar, Lakhimpur, Marigaon, Nagaon and Sunitpur). The first Health Bill initiation in India viz the Assam health Bill-2013 was awaited for his excellancy of Governor, the president of India, Mr. Pranab Mukharjee till $12^{\text {th }}$ February, 2014 and came into force from $13^{\text {th }}$ February, 2014 declared in assembly. Effective tobacco control is dependent on balanced operation of demand and reduction of supply strategies and inter and intra organisational coordination. The implementation of the Act, synergized with tobacco control initiatives by the civil society, community and NGO's are pivotal in reducing prevalence of tobacco consumption by the rural tea industrial and oil operated area of Digboi town, Tinsukia District, Assam. There is no single awareness programme at Digboi, Tinsukia district, Assam for implementation of COTPA \& the sequences of Assam Health Bill-2013. A NGO initiated awareness plan is due at Digboi in targeting it as Tobacco Free Zone.

Bibliography:

[1]. Tobacco facts.net. India Tobacco Production. Available from: URL: http://www.tobacco-facts.net/tobacco-industry/india-tobaccoproduction

[2]. Government of India. Ministry of Health \& Family Welfare, Global Adult Tobacco Survey, India, 2010.

[3]. Global map of smoke free policies; prepared for the Global Smoke free Partnership, Gillian Griffith, April 2008.

[4]. Government of Maharashtra, Public Health Department, Resolution No. CNC 1036/CR 241/PH-6, Dated 5th August 1987.

[5]. Government of India. Cabinet Secretariat O.M. 27/1/3/90 dated 7 May 1990.

[6]. Government of India. Prevention of Food Adulteration Act (PFA) (Amendment) 1990.

[7]. Karinagannanavar A, Raghavendra B, Hemagiri K, Goud TG. Awareness about pictorial warnings on tobacco products and its impact on tobacco consumers in Bellary, India. 2011;12(10):2485-9) Available from: URL: http://www.ncbi.nlm.nih.gov/pubmed/22320943

[8]. Jagdish Kaur, DC Jain Directorate General of Health Services, Ministry of Health \& Family Welfare, Government of India, India Date of Web Publication 16-Nov 2011 557X; year=2011; volume=55; issue =3; spage=220; epage=227; aulast=Kaur Available from: URL: http://www.ijph.in/article.asp?issn=0019

[9]. Revised Smoke free Rules. Notification in the Official Gazette GSR 417 (E) dated 30 the May, 2008

[10]. State Programme Implementation Plan 2011-12, National Rural Health Mission, Assam Page 596 NTCP, Assam Page 597 CHAPTER- NATIONAL TOBACCO CONTROL PROGRAMME Executive Summary Available from: URL: www.nrhmassam.in/state pip/ntcp.pdf

[11]. Government of India. National Tobacco Control Programme, 2007-08. Available from: URL: http://www.mohfw.nic.in

[12]. Government of India. Ministry of Health and Family Welfare. Directorate General of Health Services. National Tobacco Control Programme. A Guide for Teachers. [Last accessed on 2011 Aug 09]. Available from: URL: http://www.whoindia.org/LinkFiles/Tobacco Free Initiative A Guide for Teachers - Tobacco Control.pdf. 
[13]. Government of India. Ministry of Health and Family Welfare. Directorate General of Health Services. National Tobacco Control Programme. Tobacco Dependence Treatment Guidelines. [Last accessed on 2011 Aug 09] Available from: : URL: http://www.whoindia.org/LinkFiles/Tobacco Free Initiative Tobacco Dependence Treatment Guidelines.pdf.

[14]. Government of India. Ministry of Health and Family Welfare. Directorate General of Health Services. National Tobacco Control Programme. Training Manual for Doctors. [Last accessed on 2011 Aug 09]. Available from: URL: http://www.whoindia.org/LinkFiles/Tobacco_Free_Initiative_Training_Manual_for_Doctors_Tobacco_control.pdf

[15]. Government of India. Ministry of Health and Family Welfare. Directorate General of Health Services. National Tobacco Control Programme. Tobacco Cessation Manual in [Last accessed on 2011 Aug 09]. Available from: [URL] http://www.whoindia.org/LinkFiles/NMH_Resources_Tobacco_Cessation_Manual.pdf.

[16]. Government of India. Ministry of Health and Family Welfare. Directorate General of Health Services. National Tobacco Control Programme. Posters for tobacco cessation. [Last accessed on 2011 Aug 09] Available from: [URL] http://www.whoindia.org/EN/Section20/Section385_1124.html.

[17]. The Cigarettes and Other Tobacco Products (Prohibition of Advertisement and Regulation of Trade and Commerce, Production, Supply and Distribution) Act, 2003 and Related Rules \& Regulation, Ministry of Health \& Family Welfare, Government of India.

[18]. Fact Sheet, North-Estern Region, Global Adult Tobacco Survey India 2009-2010

[19]. Daulat Rahman. Enforce tobacco ban strictly, govt. told. The Telegraph, Calcutta, India.2013July22

[20]. Staff Reporter. Create a tobacco-free Assam:Gogoi. The Telegraph, Calcutta, India. 2014March2.Front page. 